\title{
DEVELOPMENTS IN APPROACHES TO HERITAGE IN ESTONIA: MONUMENTS, VALUES, AND PEOPLE
}

Heritage can be viewed from very different angles, starting from its philosophical significance all the way to its technical conservation procedures. Heritage is an extremely complex concept and pointing out all its facets and connotations may not even be possible. The contemporary approach to heritage and its significance is only one of the possible ways of interpreting and using the past. Heritage characterizes our culturally determined attitude to the past, and even if we look only at the last 150 years, the time when a modern approach to heritage has existed, we will still see tremendous changes. Just as the concepts of the past are constantly changing, so is the physical and social environment of man and heritage. The economic, social, and political changes of recent decades have also posed a serious challenge to the field of heritage. Changes taking place in the society have an inevitable impact on heritage, though at first glance it may seem paradoxical. According to the conventional approach, heritage is something that remains permanent and unchanged, even if all other things change. Heritage is something that anchors us in the past, bringing stability and security to our lives. It is true that heritage can provide durability and certainty, but it does not necessarily have to 
be the case; interestingly, it can only do so by constantly changing itself. To me, this seems to be one of the biggest paradoxes related to heritage. The alloy of permanence and changeability inherent to heritage is achieved through the constant renewal of the heritage.

Just as heritage objects and phenomena have their own story of evolution, so do approaches to heritage. The purpose of this article is to look at the ways in which heritage is approached, based on the conceptual framework of critical inheritance research. ${ }^{1}$ In case of approaches to inheritance, I distinguish between objectbased, value-based, and people-centered approaches - depending on which aspects of the heritage are at the heart of the inheritance management process. ${ }^{2}$ I use different case studies from the Estonian context as examples. The history of heritage preservation in Estonia has been repeatedly addressed in the past. ${ }^{3}$ Much less attention

1 See for example, Salvador Muñoz-Vinas, Contemporary Theory of Conservation (Oxford: Elsevier Butterworth-Heinemann, 2005); Laurajane Smith, Uses of Heritage (London and New York: Routledge, 2006); Rodney Harrison, Heritage: Critical Approaches (New York: Routledge, 2013); Tim Winter, "Clarifying the critical in critical heritage studies", International Journal of Heritage Studies, 19, 6 (2013), 532-545, Keith Emerick, Conserving and Managing Ancient Monuments: Heritage, Democracy, and Inclusion (Woodbridge: Boydell \& Brewer, 2014); The Palgrave Hanabook of Contemporary Heritage Research, ed. by Emma Waterton, Steve Watson (Basingstoke: Palgrave Macmillan, 2015); Heritage in Action: Making the Past in the Present, ed. by Helaine Silverman, Emma Waterton, Steve Watson (Cham: Springe International Publishing, 2017).

2 Conservation of Living Religious Heritage, ed. by Herb Stovel, Nicholas Stanley-Price, Robert Killick (Rome: ICCROM, 2005); Decolonising Conservation: Caring for Maori Meeting Houses Outside New Zealand, ed. by Dean Sully (Walnut Creek, CA: Left Coast, 2007); Ioannis Poulios, The Past in the Present: A Living Heritage Approach - Meteora, Greece (London: Ubiquity Press, 2014); Dean Sully, "Conservation theory and practice: materials, values, an people", The International Handbooks of Museum Studies. Museum Practice, ed. by Cona McCarthy (Chichester: Wiley-Blackwell, 2015), 293-314; Sarah Court, Gamini Wijesuriya, People-Centred Approaches to the Conservation of Cultural Heritage: Living Heritage (Rome:

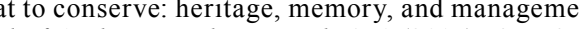
of meanings", ArchNet International Journal of Architectural Research, 9, 1 (2015), 67-76.

3 See for example, Krista Kodres, "Arhitektuuripärandi restaureerimine: ideoloogia, poliitika ja tegevuspraktika”, Eesti kunsti ajalugu, 2: 1940-1991, ed. by Jaak Kangilaski, Eneken Helme (Tallinn: Eesti Kunstiakadeemia, 2016), 407-420; Aeg ja ruит: иие muinsuskaitse poole, ed. by Anneli Randla (Tallinn: Eesti Kunstiakadeemia, 2009); Kunstiteaduslikke Uurimusi: Muinsuskaitse ja restaureerimise ajaloost. Pühendatud Villem Raami 100. sünniaastapäevale, 18 (2009); Hilkka Hiiop, Anneli Randla, "Eesti kirikute keskaegsete seinamaalingute uurimises ja restaureerimisest", Kunstiteaduslikke Uurimusi, 18 (2009), 9-43; Mälu, ed. by Anneli Randla (Tallinn. Eesti Kunstiakadeemia, 2011), Riin Alatalu, Muinsuskaitse siirdeühiskonnas 1986 2002: rahvuslikust südametunnistusest Eesti NSV-s omaniku ahistajaks Eesti Vabariigis (Tallinn Eesti Kunstiakadeemia, 2012); Anneli Randla, Hilkka Hiiop, "How Russia met Italy in Estonia. Viktor Filatov, Cesare Brandi and the conservation of medieval murals in churches on the islan tekkirma vähim Artistory Supplement, J, 2 (2013), 5971 , Ants Hein, "Et kellelgi ei peaks voli ajaloost Eestis", Maastik ja mälu: pärandiloome arengujooni Eestis, ed by Linda Kaljundi, Helen Sooväli-Sepping (Tallinn: TLÜ Kirjastus, 2014), 146-181; Aja lugu: muinsuskaitse ja restaureerimise ajaloost, ed by Anneli Randla (Tallinn: Eesti Kunstiakadeemia, 2016); Anneli Randla, Pühakodade süilitamine ja areng 2014-2018 (Tallinn: Muinsuskaitseamet, 2019). has been given to the theoretical foundations, ideas, and views of heritage management based on which practical action was used and which is taking place now. ${ }^{4}$ Existing approaches focus on the earlier period and Soviet times. However, I am particularly interested in the changes in heritage management in the time frame of the 1970s and 1980s to the present day.

\section{THE PARADIGMS OF HERITAGE MANAGEMENT}

In today's societies, heritage is addressed consciously and systematically. All activities related to heritage can be summed up under the term "heritage management." ${ }^{5}$ Heritage management involves the principles and practices of identifying, preserving, documenting, interpreting, and presenting objects, sites, and phenomena of historical, natural, scientific, or other value. Just like heritage itself, also specific ways and methods of heritage management are characteristic to a particular socio-cultural context. For heritage management, it is essential to understand the way in which the past is dealt with in contemporary socio-economic and political contexts and how it affects the definition, interpretation, use, and preservation of the heritage. Inevitably, philosophical, political and economic issues must be tackled, since the success of heritage management depends on all of them.

Heritage is affected by several processes due to which heritage is constantly changing. These changes can be caused by both natural and man-made processes, and it is impossible to stop them. Therefore, inheritance management will be able to try and manage these changes. The changes can be favorable for the inheritance,

4 Some examples of such studies include: Juhan Maiste, "Three periods in post-war Estonia restoration", Architectural Monuments in Estonia and Scandinavia: Restoration in Theory and Practice. Conference Materials. Architectural Conservation Methodology Conference Tallinn, 9-10 October 1989 (Tallinn, 1993), 200-220; Krista Kodres, "Restaurierung und da Problem der nationalen Identitat: Paradoxa der sowjetischen Kulturpolitik in Estland“", NordostArchiv: Zeitschrift fur Regionalgeschichte, 1, 6 (1997), 241-272; Eva Näripea, „Dissonantn pare ja tsionidest", Ehituskunst. Estonian Architectural Review (2005), 56-70; Kristina Jõekalda, "Võõra pärandiga leppimine ja lepitamine: 1920-1930. aastate debatid ajaloolise arhitek tu "Vi väärtuse ja kaitse üle", Mastik ja mähu: pärandiloome arengujooni Eestis, ed by (a) Kaljundi, Helen Sooväli-Sepping (Talin

5 The concept of inheritance management developed in the United States in the 1960s. In the framework of critical heritage research, this term has acquired a negative conmotion. Recently, use of the term "stewardship" has been preferred there. has a fairly neutral meaning, so I will keep using it. 
but they can also have a negative impact. In the management of heritage, efforts shall be made to promote positive effects and minimize negative effects. Heritage management is essentially a management process that has both a technical and a broader sociopolitical context. It is not a neutral technical activity, but a social process during which values and meanings are created, modified and maintained. ${ }^{6}$

Inheritance management processes can be divided according to what they focus on, into object-based, value-based, and peoplecentered processes. These are not approaches that appear in a definite temporal sequence and are necessarily mutually exclusive. Although they do have a certain temporal sequence, all of them are currently used depending on the context. Which one to prefer also depends on the purpose of the approach. These approaches represent an increasingly comprehensive and complex approach to heritage management.

Understandably, in case of object-based management, the focus of the entire management process lies on the object itself. Such an approach is certainly primary among the approaches to heritage. Since the emergence of the concept of cultural heritage at the end of the 18th century, outstanding buildings, works of art, and other valuable objects from the past characteristic of human genius were included in heritage. A characteristic feature of this approach to heritage is the recognition of heritage as a phenomenon independent of its historical-social context bearing universal values. In any case, object-based heritage management stems from the fact that first and foremost, it is important to preserve the material side of the heritage objects. Physical damage to an object means the loss of information about the past. The aim is to maintain the physical integrity of the objects, which is based on scientific research. The language spoken today is largely the language of the sciences, especially the natural sciences. And there is nothing wrong with this approach - in this way, preservation of material objects as well as information has been increasingly successful. The basic principles of object-based heritage management are reflected in the following international documents: The Athens Charter (1931), the Venice Charter (1964) and

6 Smith, Uses of Heritage, 88 the Convention Concerning the Protection of the World Cultural and Natural Heritage (1972). ${ }^{7}$

Of course, putting objects in the center of heritage management did not mean that values were completely overlooked. But both in the 19th century and much of the 20th century, the belief prevailed that values are directly and inextricably linked to the material side of objects. About two or three decades ago, questions of the value of heritage began to come to the fore more and more. This approach emphasizing value is called value-based management. After all, the importance of objects lies to a large extent in the values and meanings that people associate with them. Objects or phenomena are considered to be heritage only when they have been given certain historical, scientific, aesthetic, artistic, social, or other value. ${ }^{8}$ It is values that make an object or phenomenon a heritage. Values appear as a result of the interaction between the object, its context, and people. Thus, in case of a value-based approach, the physical integrity of an object is still at the center, but its various values are also considered. The same object can carry different values, depending on the point in time and the owners of the value, which values are assigned to the object or phenomenon and which values are considered important. However, decision-making processes concerning heritage management are usually guided by experts, although other stakeholders, such as local people, users of the objects, artists, owners, creators of heritage objects, museum staff and others, are involved. In this case, we are talking about shared decision-making. To date, a value-based approach has been clearly reaffirmed in heritage management. The principles of value-based management were reflected in the Burra Charter (1979) and the Nara Document on Authenticity (1994). ${ }^{9}$

7 The Athens Charter for the Restoration of Historic Monuments (ICOMOS, 1931), https:// www.icomos.org/en/167-the-athens-charter-for-the-restoration-of-historic-monuments (accessed on 21.08.2019); International Charter for the Conservation and Restoration of Monuments and Sites (The Venice Charter 1964) (International Council on Monuments and Sites), https://www. icomos.org/charters/venice_e.pdf (accessed on 21.08.2019); UNESCO, Basic Texts of the 1972 World Heritage Convention (Paris: UNESCO, 2005).

8 Kurmo Konsa, Laulupidu ja verivorst: 21. sajandi vaade kultuuripärandile (Tartu: Tartu Kõrgem Kunstikool, 2014), 67-82.

9 The Burra Charter (Burwood: Australia ICOMOS Incorporated, 2000), http://australia. icomos.org/wp-content/uploads/BURRA_CHARTER.pdf (accessed on 21.08.2019); The Nara Document on Authenticity (ICOMOS, 1994), https://www.icomos.org/charters/nara-e.pdf (accesse on 21.08.2019). 
The new approach, which puts the individual at the heart of the entire inheritance management process, is known as people-centered heritage management. Heritage is linked to people's lives in many ways, and this is what the name of this approach suggests. The focus shifts to how the heritage creation process and its outcome affect people. What is central is no longer the material object as the bearer of values, but the community that attaches these values to the object. Maintaining and shaping the well-being and values of today's communities drive the entire process. With this approach, creating heritage starts from defining values and ideas that we value and want to promote. When creating a heritage, it is not a material object that is defined, nor is it a material object that has values, instead, it is social networks that connect objects with meanings and values to people and societies. Just like the past, heritage is something that people are constantly transforming and creating. It is an approach that emphasizes heritage creation taking place at a given time. The specific objects and phenomena that manifest the inherent values of the heritage are of secondary importance. Within this framework, the main emphasis has shifted from the content or structure of the heritage to the heritage as a process. Heritage is an active process through which one perceives, understands, and reshapes the world Heritage is not a "thing" but a cultural practice that participates in the creation and organization of values and perceptions. ${ }^{10}$

The people-centered approach began to emerge a little over ten years ago - in the 2000s. The principles of people-centered heritage management have been reflected in the following documents: Convention for the Safeguarding of the Intangible Cultural Heritage (UNESCO 2003), the Council of Europe Framework Convention on the Value of Cultural Heritage for Society (Faro Convention, 2005) Preservation for People: A Vision for the Future (National Trust for Historic Preservation 2017). ${ }^{11}$ The increasing spread of the peoplecentered approach, which places heritage above all in the context of community development, has led to changes in the entire domain of

10 Smith, Uses of Heritage, 11.

11 UNESCO, Convention for the Safeguarding of the Intangible Cultural Heritage (Paris: UNESCO, 2003); Council of Europe Framework Convention on the Value of Cultural Heritage for Society (2005), http://conventions.coe.int/Treaty/EN/Treaties/Html/199.htm (accessed on 1.08.2019); National Trust for Historic Preservation, Preservation for people: a vision for future (Washington DC: National Trust for Historic Preservation, 2017).

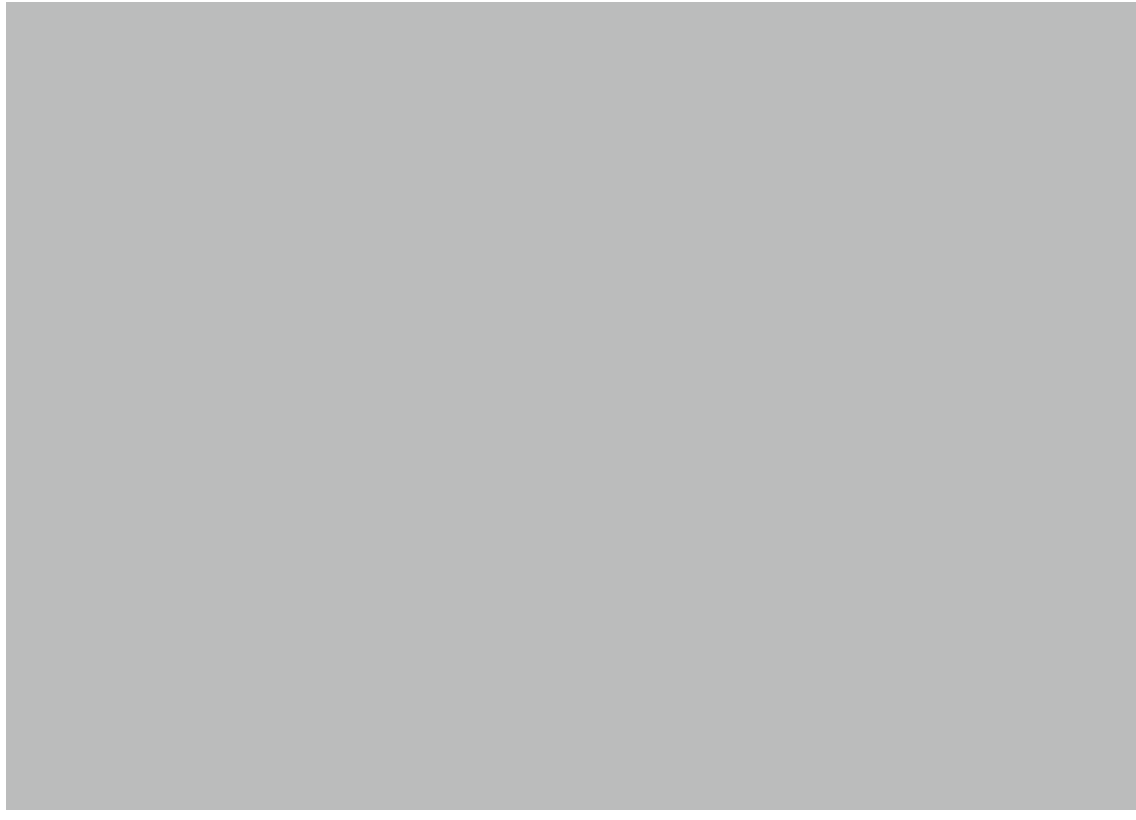

FIG. 1. KALVI ALUVE, THE STORY ABOUT ARCHITECTURAL MONUMENTS (1983). PHOTO: KURMO KONSA.

heritage, in how heritage is created, perceived, valued and preserved The approach that began with the management of the heritage of indigenous peoples is also widespread in the case of so-called classic heritage objects - buildings, historic cities, and archaeological sites.

In the following, we will look at the development of heritage management processes in Estonia, based on the object, values, and people-centered approach described above.

\section{OBJECT-BASED HERITAGE MANAGEMENT IN ESTONIA -} “THE STORY ABOUT ARCHITECTURAL MONUMENTS"

In order to describe object-based heritage management, I will use Kalvi Aluve's book "The story about architectural monuments" (1983) (Fig. 1). It is a popular work targeted for the general public, which is why many of the views and concepts that are obviously used on a 
daily basis by those involved in the matter and have often become an invisible part of the work culture, are explained in detail and defined. As the architectural historian and restorer, Kalvi Aluve (1929-2009) worked from 1957 to 1995 at the National Institute of Research and Design "Estonian Architectural Monuments," ${ }^{12}$ in the years 1968-1978 as chief architect and since 1992 as the leading architect, this book also partly presents the views that form the institutional foundations of official heritage conservation. Which, of course, does not mean the absence of different views. In his work, the author has criticized quite a number of restorations. ${ }^{13}$ There have been attempts to divide the Soviet-era restoration concepts into periods, but this may be too much of a generalization. Much depended on the individuals and their perceptions of the specific objects to be restored, but also on material resources and people. ${ }^{14}$

The author bases his views mainly on the Venice Charter, the first translation of which in Estonian has been provided in the annex of this book. ${ }^{15} \mathrm{He}$ emphasizes the validity of its views, points out the clarity and brevity that is very important in practical restoration. ${ }^{16}$ The Venice Charter was drafted at the Second International Congress of Architects and Technicians of Historical Monuments in Venice in 1964. In the next year, in 1965, the Venice Charter was endorsed by the International Council of Monuments and Sites (ICOMOS) in Krakow, Poland, on $1^{\text {st }}$ General Assembly. In addition to the countries of Western Europe, the Soviet Union and the countries of the socialist block were involved in the development of the charter. The Venice Charter emphasizes the importance of authenticity, as stated in its preamble: "People are becoming more and more conscious of the unity of human values and regard ancient monuments as a common heritage. The common responsibility to safeguard them for future generations is recognized. It is our duty to hand them on in the full richness of their authenticity."17 Authenticity is related to the

12 Kalvi Aluve, Veste ehitusmälestistest (Tallinn: Eesti Raamat, 1983), 12, 38, 56, 68, 72, etc.

13 Ibidem.

14 Kodres, "Arhitektuuripärandi restaureerimine: ideoloogia, poliitika ja tegevuspraktika", 417.

15 Aluve, Veste ehitusmälestistest, 98-101.

16 Ibidem, 5.

17 International Charter for the Conservation and Restoration of Monuments and Sites (The Venice Charter 1964) (International Council on Monuments and Sites), https://www.icomos. org/charters/venice_e.pdf (accessed on 21.08.2019). historical value of objects and this in turn to material originating from a given period. It is assumed that history is in some way stored in objects that make them unique witnesses of history. Once the authenticity of the material has been established, the object automatically acquires historical value. ${ }^{18}$ This is especially noticeable in the case of archaeological finds. Historical value is the eigenvalue of objects, which only depends on time.

Heritage management based on authenticity, thus focuses on preserving the past and its material traces. Authentic heritage is a non-renewable resource and must be preserved for future generations. These principles are also the underlying principles of object restoration, such as minimum intervention, respect for historical evidence, avoidance of falsification, preservation of the original, reversibility of interventions, compatibility of materials used and the distinction between the original and the impurities.

It is characteristic to emphasize ethnicity, for the modern concept of heritage was very closely related to the formation of nations and nation-states in the 19th century because heritage played an important role in securing and harmonizing the identities of states and nations. ${ }^{19}$ It can be said that defining a common cultural heritage was one of the foundations of the emergence of nation-states. This emphasis on the relationship with ethnicity continued in the object-based paradigm. Thus, according to Aluve, for example, the older Estonian architecture is divided into two groups, one created by indigenous people Estonians and the other by non-Estonians. ${ }^{20}$ The heritage embodies the spirit of the people, its deeper essence: "As we have seen, the architectural heritage of the past, which represents a unique cultural value and is one of the proofs of the continuity of life, reflecting the creative spirit of different nations over the centuries, is an important enriching factor of our lives." ${ }^{21}$

18 Randall Mason, "Assessing Values in Conservation Planning: Methodological Issues an Choices", Assessing the Values of Cultural Heritage: Research Report, ed. by Marta de la Torre (Los Angeles: The Getty Conservation Institute, 2002), 5-30, 13.

19 Diane Barthel, Historic Preservation: Collective Memory and Historical Identity (Newark, NJ: Rutgers University Press, 1996); Gabi Dolff-Bonekämper, "The social and spatial framework of heritage - What is new in the Faro Convention?", Heritage and Beyond (Strasbourg: Council of Europe Publishing, 2009), 69-74; Susan Pearce, Collecting in Contemporary Practice (London: Sage, 1998)

20 Aluve, Veste ehitusmälestistest, 8.

21 Ibidem, 95 
Heritage is managed by experts, whereas the general public forms an abstract audience that uses the heritage they present. The stakeholders related to the heritage are identified, evaluated, and involved by official experts. ${ }^{22}$ The circle of these experts is very narrow: "For the most part, the restorers, that is, authors of restoration projects, are either architects or art historians. The latter, however, mostly at the "dead" architectural monuments that need to be conserved..$^{23}$ By default, it is expected that the solutions suggested by the experts are always suitable for people and, if the solutions suggested to people are not suitable, they must be further developed: 'It is not acceptable that the so-called mass tourist level begins to determine the restoration activity, forcing even scientifically sound principles to be ignored. Man's cultural level is growing, his perceptions are approaching those of scientists, and then he is no longer satisfied with a substandard exhibit." ${ }^{24}$

Heritage is still used to teach people in the spirit of the Enlightenment: "We are protecting architectural monuments not only to preserve them but also to raise the cultural level of the people, to gain useful knowledge from them." 25 "Architectural monuments are a common asset of the nation. Because of their aesthetic value, they play an important educational role." 26 "Architectural monuments play an important role in the ideological-political upbringing of people, helping to raise the general level of culture, increasing pride in the achievements of their people, developing artistic taste." 27

The use of heritage is important but not essential: "The use of cultural monuments must contribute to the preservation of cultural heritage but must not become dominant in the overall restoration

22 Sian Jones, "'They made it a living thing didn't they...": The growth of things and the fossilization of heritage", A Future for Archaeology: the Past in the Present, ed. by Robert Layton, Stephen Shennan, Peter Stone (London: UCL Press, 2006), 107-126, quote from page 111; Henry Heritage Management in the Modern World, ed. by Henry Cleere (London: Unwin Hyman, 1989), 1-19, quote from pages 10-11; Tim Schadla-Hall, "Editorial: Public Archaeology", European Journal of Archaeology, 2, 2 (1999), 147-158, quote from page 156

23 Aluve, Veste ehitusmälestistest, 21.

24 Ibidem, 36. Compare also: Denis Byrne, "Chartering Heritage in Asia’s Postmodern World", Conservation, 19, 2 (2004), 16-19.

25 Aluve, Veste ehitusmälestistest, 97.

26 Ibidem, 21.

27 Ibidem, 42 activity, as it used to be a few years ago. More than ever, we were then only dealing with architectural monuments that could be adapted to new features. And less than ever in the post-war restoration, we engaged in conservation. Conservation is and will continue to be one of the most important tools for extending the age of architectural monuments." ${ }^{28}$ The use of heritage objects is subject to their preservation, with a very clear emphasis on conservation.

Heritage management is ideally based on a strictly scientific approach: "Restoration is more science than art; it requires a lot of thinking." 29 The author emphasizes that "the views or opinions presented are based on generally valid objective observations." ${ }^{30}$ The author complains that in real work, the scientific approach may be lacking, but this is compensated by a closer link with the practice: "As a practitioner-researcher-restorer, the author of this book does not follow strict scientific research practices. They simply cannot be followed in a non-scientific institution. However, there are some good points to it, especially the close link between theoretical research and practice." 31

\section{VALUE-BASED HERITAGE MANAGEMENT - THE RESTORATION OF THE INDEPENDENCE AND HERITAGE PROTECTION MOVEMENT}

Value-based inheritance management sets at the heart of heritage the values attributed to heritage by the various stakeholders in society. While in object-based heritage management people act as groups against the backdrop of monuments, this approach shifts the values that people attach to heritage objects and heritage phenomena to the forefront. A value-based approach to heritage was introduced quite unexpectedly in Estonia in the late 1980s, in connection with the independence movement. The second, however, a very related area, where the political activity of the people also channeled, was environmental protection, but I am not going to address this in the article, although the links thereof with heritage are obvious.

28 Aluve, Veste ehitusmälestistest, 13.

29 Ibidem, 81

30 Ibidem, 4.

31 Ibidem, 75. 
In the mid-1980s there were several heritage associations operating in Estonia. The main activities included organizing presentation evenings, visiting cultural-historical sites, but also arranging and restoring various objects such as churches, churchyards, and cemeteries. ${ }^{32}$ On October 18, 1986, a meeting of heritage conservation clubs, which can be considered the beginning of the heritage protection movement spreading all over Estonia took place in Jüri. The second meeting of heritage conservation clubs took place on February 7, 1987, at Tallinn Cinema House. Presentations and discussions held there took a broader and more value-based view of heritage and its management: "Layer by layer, the spiritual program of the entire heritage conservation movement was brought into the daylight. Cultural memory is consistent. Keeping it is a prerequisite for the survival of the nation and the duty of the people themselves. Lennart Meri emphasized that the concept of heritage should be interpreted generously. This means that heritage is everywhere where there are people and where time does its work." 33 Along with the emergence of perestroika and political movements, the heritage protection movement acquired a clearly political character: "After Hirvepark and Tarvastu, a lot changed. The heritage movement clearly acquired an undertone of political struggle or freedom fight. Of course, it was clear to many that the heritage of heritages was the Republic of Estonia. That without true independence, nothing can come out of the protection of heritage." ${ }^{34}$

On December 12, 1987, the Estonian Heritage Society (EHS) was established in Tallinn. The membership of the Society grew exponentially, so by the end of 1988 there were 185 local cells all over Estonia with more than 6000 members. The Society was actively involved in the restoration of cemeteries of those killed during the War of Independence and in the re-erection of monuments (more than 120 memorials were restored). Under the aegis of the Historical Committee of the EHS, a campaign of collecting memories was launched that was compared to Jakob Hurt's mission of collecting folklore (with more than 20,000 pages

32 See for example, Jaan Tamm, "Kuidas asutati Eesti Muinsuskaitse Selts", Eesti Muinsuskaitse Selts 25 (Tallinn: Eesti Muinsuskaitse Selts, 2012), 12-25.

33 Trivimi Velliste, "Eesti Muinsuskaitse Seltsi tekkelugu ja väljakujunemine", Eesti Muinsuskaitse Selts 25 (Tallinn: Eesti Muinsuskaitse Selts, 2012), 26-53, quote from page 31.

34 Ibidem, 36. collected with 400 helpers). Memories and reminiscences were collected on topics that were still hidden from the public (Soviet annexation of Estonia, Soviet repressions, deportations, political prisoners and forest brothers). On April 14-17, 1988, the Heritage Conservation Days of the EHS were held in Tartu where for the first time the national flag of Estonia was brought out in the daylight. Together with the Estonian National Independence Party and the Estonian Christian Union, the Estonian Heritage Society was also the initiator of the Citizens' Committees movement. Political activity was the main goal of the then Heritage Conservation Society. "It was a special service of the Heritage Conservation Movement to be a pioneer," says Trivimi Velliste. "As the first large-scale freedom movement, it was built on a historical parish basis and created the model for the emergence of citizens' committees two years later Estonia retained its historical roots, its spiritual heritage and the legal continuity of the state." Eenok Haamer adds that the heritage conservation movement was not aimed at preserving old values, but could serve as a cover for Estonia's independence movement. ${ }^{35}$ The most obvious feature of heritage conservation was the idea of restoration - restoring everything valuable from the former Republic of Estonia. ${ }^{36}$ Adherence to the principle of legal continuity directly linked the political struggle to heritage, which in this case was the former Republic of Estonia. The Heritage Society was the first patriotic mass organization in Estonia. Because the Society was involved in a so-called practical policy that was well understood by people and enabled them to participate actively, it became very popular. The Estonian Heritage Society was undoubtedly one of the initiators and important participants of the national revival movement. ${ }^{37}$ Characteristically to value-based heritage management, the values related to independence and sovereignty attributed to objects became more important to people than the concrete objects themselves.

35 Kadri Paas, "Kuidas KGB kollitas muinsuskaitsjaid", Maaleht, 28.09.2012, http://www maaleht.ee/news/uudised/elu/kuidas-kgb-kollitas-muinsuskaitsjaid.d?id=65020388 (accessed on 21.08.2019).

36 Marek Tamm, Monumentaalne ajalugu: Esseid Eesti ajalookultuurist. Loomingu Raamatukogu nr 28-30 (Tallinn: SA Kultuurileht, 2012), 109.

37 Toomas Karjahärm, Väino Sirk, Kohanemine ja vastupanu. Eesti haritlaskond 1940-1987 (Tallinn: Argo, 2007), 522 . 
As political forces and political struggles developed, purely political movements and associations became important. On February 19, 1990, just before the election of the Estonian Congress, the Executive Committee of the EHS decided to abandon politics and henceforth focus solely on heritage conservation. It was also the beginning of a sharp decline in the membership and popularity of the Society. The activities of the Society returned to the so-called classic heritage objects (buildings, monuments, etc.). This also involved the replacement of the value-based approach with the object-based approach. The paradigm of value-based heritage management then shifted to the area of natural sacred places.

\section{THE IDENTITY AND NATURAL SACRED PLACES}

\section{OF EARTH FAITH (ESTONIAN NATIVE RELIGION)}

Earth faith is a new religion that emerged in Estonia in the 1980s, which is, to a large extent similar to the Neopagan religious movements in other parts of the world. In part, Earth faith is based on Taara faith dating back from the 1920s. Favorable environment for that was also the Finno-Ugric tribal movement, which became very popular in the 1990s. In 1995, the House of Taara and Native Religions (HTNR) was founded. ${ }^{38}$ The number of active Earth faith believers in Estonia is quite small, while the popularity and influence of Earth faith in society are considerable (Altnurme, 2005). ${ }^{39}$ Earth faith presents itself as the only original faith of the indigenous people in Estonia whose origins can be traced back to pre-Christian paganism. According to this view, Earth faith has emerged with rural people ("people of Earth") and they have carried on the faith unchanged until today. The influence of the Earth faith movement is largely due to the fact that Earth faith believers use cultural heritage, in particular, intangible and natural heritage, to create and consolidate their identity and to promote their views. Initiating and leading the movement for the protection of natural sacred places has played a very important part

38 See for example, Triin Vakker, "Rahvusliku religiooni konstrueerimise katsed 1920. 1930. aastate Eestis - taara usk", Mäetagused, 50, 1 (2012), 175-198; Ergo-Hart Västrik, "In Discourse", Contemporary Pagan and Native Faith Movements in Europe: Colonialist and Nationalist Impulses, ed. by Kathryn Rountree (Oxford: Berghahn, 2015), 130-153.

39 Lea Altnurme, "Religiooni uurimise probleemidest sotsiaalkonstruktsionistlikus perspektiivis", Usuteaduslik Ajakiri, 60, 1 (2010), 4-22. of awareness of the existence of Earth faith. In 2005, the conference "Historical Natural Sacred Places of Estonia Yesterday, Today, and Tomorrow" was held at the National Library under the leadership of Maavalla Koda (literally House of the Native Land) and the presentations were also published as a book. ${ }^{40}$ In 2008, the National Development Plan "Historical Sacred Places of Estonia, Research and Preservation, Sectoral Development Plan 2008-2012, "the overall aim of which was to preserve the uniqueness of Estonia's natura sacred places and related intangible cultural heritage, was adopted. A center for historical sacred places was established at the Faculty of Philosophy of the University of Tartu. The development plan defined historical sacred places as places with a natural appearance, associated with folkloric, archaeological, historical, ethnological or other data referring to sacrifice, sanctification, healing, praying or other religious or ritual activity. The development plan covers the areas and monuments, the active use of which dates back to the time preceding the 20th century. To implement the development plan, the House of Taara and Native Religions, the HTNR, established the Foundation House of the Groves in 2008. Its purpose is to study, introduce, and preserve the natural sacred places of Estonia and, more broadly, the heritage culture and living environment of the indigenous people of Estonia. In 2015, the next development plan, "Estonian Natural Sacred Places, Research and Preservation, Development Plan 2015-2020"41 was adopted. The overall objective of the Development Plan is to preserve Estonian natural sacred places for the present and future generations through their identification (inventory), data availability, and valuation. The implementation of the Development Plan will provide an overview of the number location, and boundaries of the sacred places. ${ }^{42}$

The Earth faith believers emphasize the origin and connection of their religion as well as the natural sacred places with essentially undated prehistory. Objects and landscapes identified as natural sacred places date back to very different periods and have been

40 Looduslikud pühapaigad: Väärtused ja kaitse, comp. by Ahto Kaasik, Heiki Valk (Tartu: Õpetatud Eesti Selts, 2007), http://maavald.ee/hiis/raamat2007/hiiekogumik.pdf (accessed on 21.08.2019)

41 Eesti looduslikud pühapaigad. Research and Preservation. Development Plan 2015-2020 (Tallinn: Ministry of Culture, 2015).

42 Ibidem, 9. 
used for very different purposes. ${ }^{43}$ Often, they have important historical and aesthetic or nature conservation value. However, the most important aspect of heritage is undoubtedly their social value, which is that they are currently valued and considered important by the community, which defines itself as Earth faith believers. Thus, the scientific identification of other values, which may be difficult or even impossible, is not essential for the preservation of these objects.

Dealing with natural holy places raised a number of important issues that had not yet been encountered in heritage conservation. Until then, heritage conservation had been dealing with sacral buildings that were either owned or rented by religious associations. Natural sacred places, on the other hand, are generally not owned by a religious community, with the exception of sacred places on privately owned land, the owners of which are themselves members of the respective community. Thus, the interests of different groups often clash in natural sacred places. To illustrate this, we will hereby bring a description of the case of Ebavere Hill.

\section{THE CLASH OF DIFFERENT VALUES ON EBAVERE HILL}

Ebavere Hill is located in Lääne-Viru County, south-southwest of Väike-Maarja, near Ebavere. Ebavere esker is one of the most expressive forms of the Nõmme-Ebavere edge formation. Ebavere Hill is a steep, $35 \mathrm{~m}$ high, elongated hill covered with forest which belongs to the Porkuni-Rakke esker system. The highest altitude is 146 $\mathrm{m}$ above sea level, making it the third-highest hill in the Pandivere Upland. The hill consists of gravel and sand. Morphologically, it is one of the irregular, broad eskers with hollows and side valleys on its sides. The southern slope is the steepest (up to $33^{\circ}$ ) with a 5-6 m terrace on the northeastern side. A 39-hectare landscape reserve was created in 1959 to protect the hill. ${ }^{44}$ Thus, the hill is a national heritage site and is managed in accordance with the Nature Conservation Act and the Ebavere Landscape Conservation Area Conservation Rules

43 Tõnno Jonuks, "Hiied Eesti pühapaikade uurimisloos", Mäetagused, 42, (2009), 33-54, http:// www.folklore.ee/tagused/nr42/jonuks.pdf (accessed on 21.08.2019).; Tonno Jonuks, Mart

44 Approval of the protection rules and description of the external border of the Ebavere landscape protection area (1998), https://www.riigiteataja.ee/akt/76383 (accessed on 21.08.2019). Ebavere Landscape Protection Area (KLO1000465). EELIS, http://loodus.keskkonnainfo.ee eelis/ (accessed on 21.08.2019) (approved by the Regulation of the Government of the Republic in 1988). The protection area is divided into two types of zones according to the nature of the protection regime and the degree of restriction of economic activity: the special management zone and the limited management zone. In accordance with the general principles of the protection regime of the protected area, camping and campfires are permitted only in the places designated by the administrator of the protected area, and on privately owned land, with the permission of the owner. Public events with up to 50 participants are allowed in the protected area. Public events with more than 50 participants are allowed only with the consent of the administrator of the protected area. As the protected area is a popular ski area, a sports center has been established on the hill.

The hill is considered a holy place by the members of the Estonian new paganist Earth faith religious movement, who hold a celebration there around the All Souls Day, remembering their ancestors and Earth gods (Fig 2). On October 28, 2012, Viru House of the Earth faith believers organized an All Souls Celebration on the grove located on Ebavere Landscape Protection Area and informed the public about it in advance. Following historical practice, two small campfires were lit for prayer in the remotest part of the hill. Representatives of Udmurdi and Mari indigenous religion also attended the event. After the participants of the ritual departed, an environmental inspector observed the site. The next few days, the Mayor of Väike-Maarja Rural Municipality and the Environmental Inspectorate demanded explanations from the Earth faith believers. The House sent a letter of formal notice to the authorities stating that officials' reactions to the prayer on Ebavere Hill have been exaggerated and could be considered as religious persecution. ${ }^{45}$ In the course of more than half a year of investigation, the Environmental Inspectorate interviewed members of the management board of the Viru House of Earth Faith Believers. Leili Tuul, a spokesman for the Environmental Inspectorate, said that the Viru House of Earth Faith Believers made fire in the Ebavere Landscape Protection Area, in the state forest, in a place not designated, unprepared and marked for that, without the consent of the manager of the protection area and the landowner, the State Forest

45 "Keskkonnainspektsioon määras maausulistele hiies lõkke tegemise eest trahvi", Postimees 14.07.2013, http://www.postimees.ee/1269794/keskkonnainspektsioon-maaras-maausulistelehiies-lokke-tegemise-eest-trahvi (accessed on 21.08.2019) 


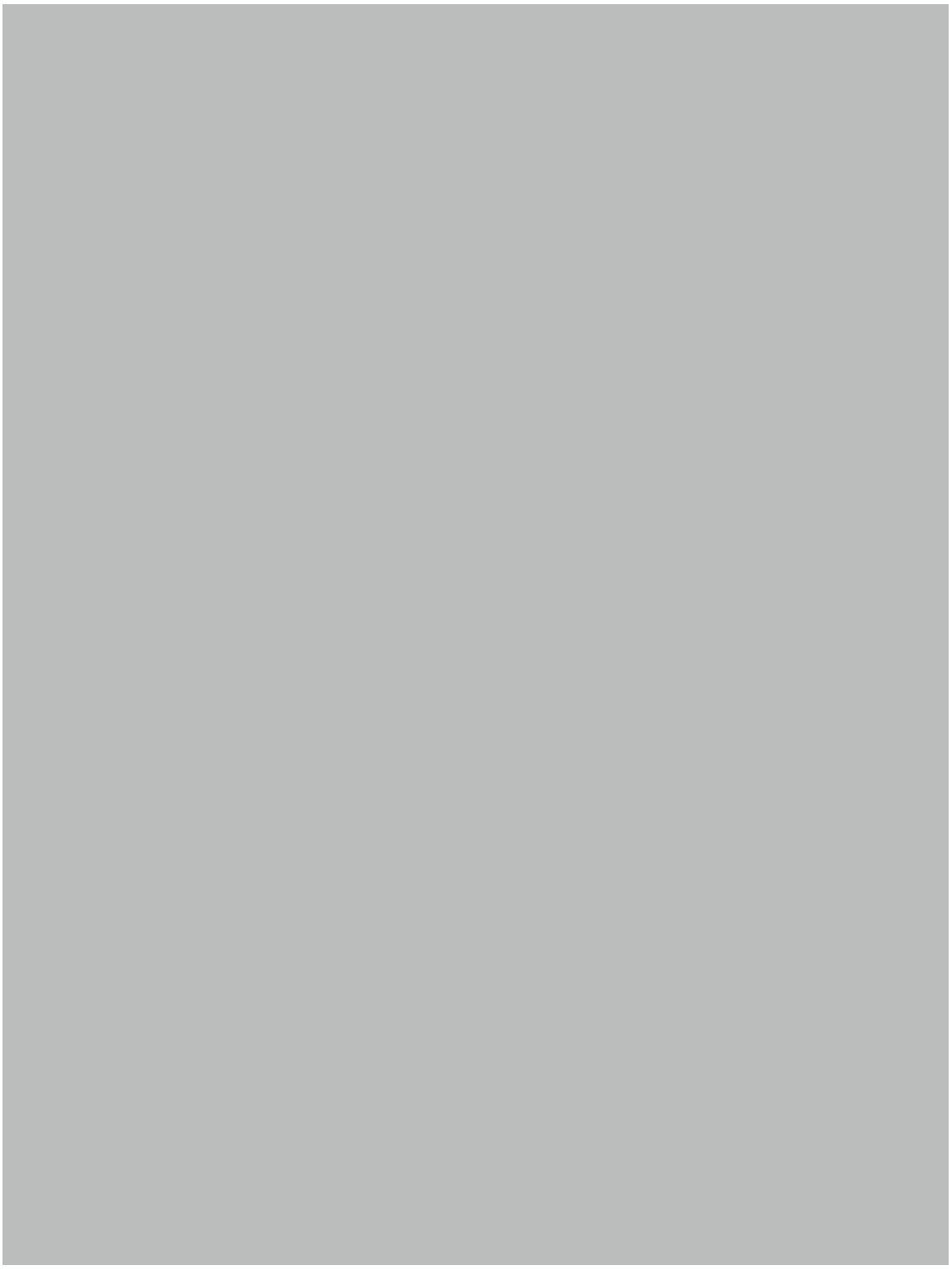

FIG. 2. EBAVERE HILL IS CONSIDERED A HOLY PLACE BY THE MEMBERS OF THE ESTONIAN NEW PAGANIST EARTH FAITH RELIGIOUS MOVEMENT. PHOTO: KURMO KONSA.
Management Center. According to the Environmental Inspectorate, the inspectorate does not persecute Earth faith believers, and the Nature Conservation Act applies to everyone regardless of religious beliefs. "The Environmental Inspectorate monitors compliance with nature conservation requirements, and regardless of religious beliefs, the Nature Conservation Act applies equally to everyone in the protected area. Therefore, it is not a question of obstructing religious practice or religious persecution as currently interpreted and presented by the House of Taara and Native Religions, but of meeting environmental requirements," Tuul noted. ${ }^{46}$ In June 2013, the parties agreed to an expedited misdemeanor proceeding and the Earth faith believers will have to pay a fine of EUR 100 for making a fire in the grove during prayer.

Ebavere Hill is a heritage at both national and community level. In the latter case, the main value is the social value, since a certain community (the Earth faith believers) uses the grove on the hill to carry out its rites. The problems arose from the incompatibility of the values of the two levels of heritage and the holding of some values, in this case, national values, at the higher esteem. To address this situation, it is necessary to regulate the use of national monuments by other stakeholders, as was the case with Stonehenge, a World Heritage Site in England since 1986. Stonehenge had attracted neopagan worshipers already since 1905 when the ancient Druidic Order performed a sun-worshiping ritual there. Due to the erosion of stone monuments, access to them has been restricted since 1977 and restrictions were increased in 1985. Since 2000, on the solstices, access to monuments has been given to neo-pagan communities, and they have a possibility to carry out their rituals. ${ }^{47}$

After the emergence of a value-based approach in the second half of the 1990s, heritage management has increasingly favored participatory processes, the involvement of different views and stakeholders, rather than top-down approaches. It can increase the number of people interested in heritage and thus ensure more sustainable management of the heritage. Traditionally, heritage decisions are still made by

46 "Keskkonnainspektsioon: me ei kiusa maausulisi taga", Postimees, 14.07.2013, http:// www postimees ee/1270120/keskkonnaispektsioon-me-ei-kiusa-mausulisi-taga (accessed on 21.08.2019).

47 Stonehenge. English Heritage, http://www.english-heritage.org.uk/daysout/properties/ stonehenge/ (accessed on 21.08.2019). 
experts, but it would be great if there was much greater involvement of owners and stakeholders in heritage management. But how can this be achieved? It is not possible to involve other stakeholders if they have no real decision-making power in the heritage management processes. However, this requires that they have both the rights and the means to do so, only then will people be directly connected to the heritage and its use and preservation will be organized in the best way. Stakeholders involved in a given heritage must be given the same decision-making powers as to experts. It seems reasonable that all interested parties are considered as experts in making decisions on heritage, regardless of whether they are scientists and planners or representatives of the local population, and their views are treated as equals. ${ }^{48}$

The value-based approach to heritage management puts communities and the values attributed by them to the heritage at the forefront, be they freedom and independence of the Estonian people, as we saw in the analysis of the heritage movement in the 1980s and 1990s, or the holiness that the Earth faith believers attribute to natural sacred places. The value-based approach, however, greatly expands the concept of heritage, including spiritual aspects of the intangible heritage and material objects and the environment. However, in practical heritage management, experts and existing institutions remain in power.

\section{PEOPLE-CENTERED HERITAGE MANAGEMENT AND PHILOSOPHICAL THOUGHT}

The decision to preserve something for future generations is, above all, a philosophical and ethical issue. ${ }^{49}$ People-centered inheritance management starts with addressing these issues. Juhan Maiste is the only one who has dealt with these problems in connection with

48 Ned Kaufman, "Putting Intangible Heritage in its Place(s): Proposals for Policy and Practice", International Journal of Intangible Heritage, 8 (2013), 29-36, quote from page 29.

49 See for example, Angela M. Labrador, Neil Asher Silberman, "Introduction: public heritage as social practice", The Oxford Handbook of Public Heritage Theory and Practice, ed. by Angela M. Labrador, Neil Asher Silberman (New York: Oxford University Press, 2018), 1-17, quote from page 2 . the Estonian heritage conservation in several articles and books. ${ }^{50}$ Below I will analyze his approach and try to highlight the connections with people-centered heritage management.

Maiste's approach is based on philosophy, first and foremost on phenomenology and art history, and finds expression in high style essayist texts. Not surprisingly, practically oriented heritage conservationists are unable to take a stand on them. He recognizes and clearly expresses the need for new heritage protection and also presents to us its essence: "Heritage conservation strives out from the frames that have become too constraining for it. It steps from the temple to the street, talks to the big one and the small one, using the language and words that were previously permitted solely to philosophers. Heritage protection speaks of time and space. As if someone had given it the right to do so. It speaks of a world filled with a gazillion of little things that find their true meaning not so much in the things themselves, but in the meanings we have given them. It speaks not only of objective reality but also of its place in the subjective memory of a person. Thus, not only of the monuments but to the equal extent of the time and space to which the monuments inevitably belong." ${ }^{11}$ Today's concept of heritage has become extremely inclusive - an approach initially embracing only valuable buildings and works of art has become a concept that encompasses virtually all human objects as well as the natural environment. But all these "gazillion" specific objects and phenomena per se are not relevant to heritage management. What is important is the values and meanings that people attach to objects. Objects, phenomena, locations, and people will not become heritage until they are recognized as such by people. Thus, heritage as such does not exist in any essential form, independent of the opinion of people.

In Maiste's opinion, the starting point for a new heritage conservation must be in this time, in our present life, not in the past: "If the obligation of heritage protection inherited from the 20th

50 Juhan Maiste, Tuldud teed edasi $=$ Along the Trodden Path, ed. by Eva Näripea (Tallinn: Eesti Kunstiakadeemia, 2007); Juhan Maiste, "Kunstikriitiline ja kriitiline restaureerimine", Technology, 2008), 133-143: Juhan Maiste, "Aeg ruumis ja rum ajas: tagasi asjade juurde", Aeg ja ruum: uue muinsuskaitse poole, ed. by Anneli Randla (Tallinn: Eesti Kunstiakadeemia, 2009), 9-16; Juhan Maiste, "Vabadus mäletada", Akadeemia 5 (2010), 778-794; Juhan Maiste, Kolmas silm: essee ilusast maastikust (Tallinn: Varrak, 2011); Juhan Maiste, Vabadus mäletada, comp. by Kadri Asmer (Tartu: Ilmamaa, 2016).

51 Maiste, "Aeg ruumis ja ruum ajas: tagasi asjade juurde", 12. 


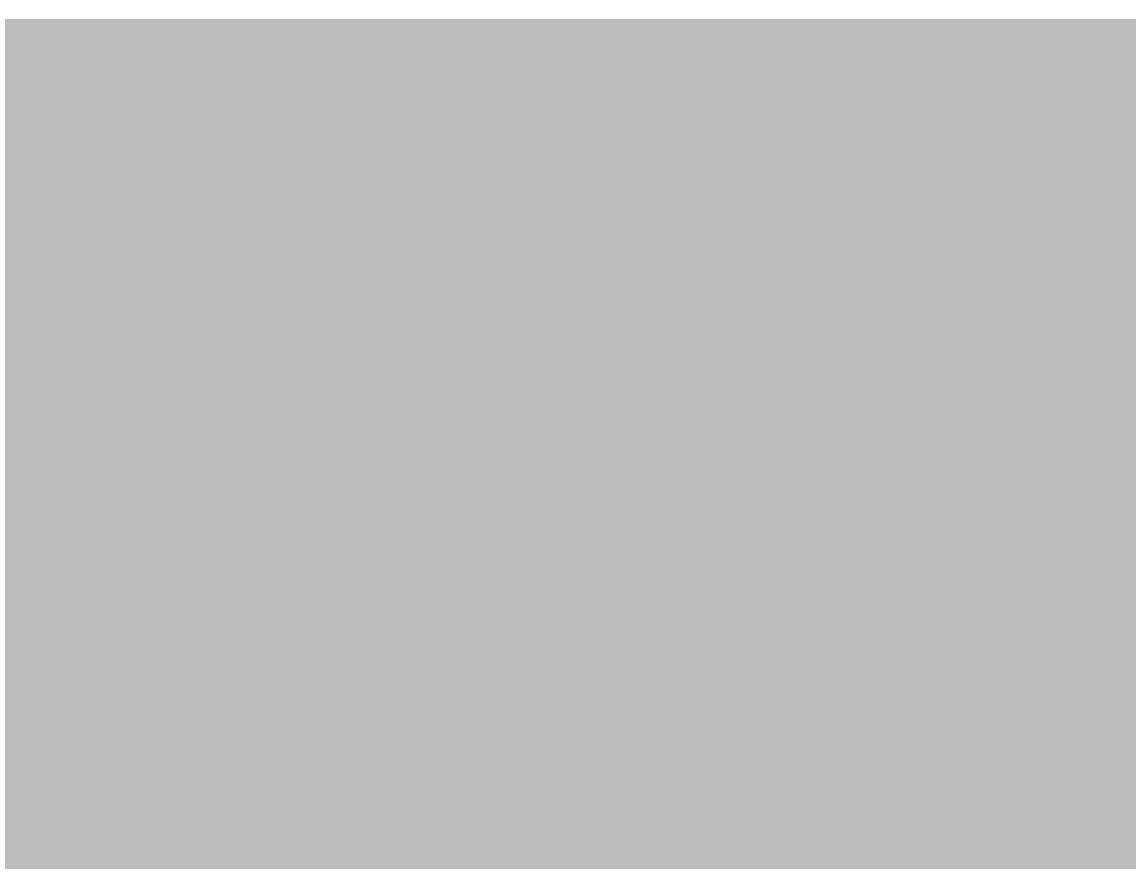

FIG. 3. VASTSELIINA EPISCOPAL CASTLE. PHOTO: KURMO KONSA.

century [...] was to stand up for someone or something, protect us from the 'evil eye and the hairy hand', retreat behind the walls of fortresses and monasteries (where the last monks have long since left), the expectations that heritage conservation could and should meet have by now changed significantly. Alongside the objective reality of heritage conservation (as it was understood in much of the 19th century), the new heritage protection invites us to address the environment and our own role in it: not to talk about the world as it manifested itself in the Age of Enlightenment, but as it presents itself to us now." ${ }^{2}$ (Fig 3)

Above all, people-centered heritage management means creating values and meanings directed in the future. In a sense, it's about

52 Maiste, "Vabadus mäletada", 779 turning perspective from the past into the future. Heritage is not something of the past, but something directed towards the future. It is a social and cultural resource that underlies planning of the future. I think this is the most important function of heritage in general. Heritage management is the reinterpretation of contemporary social and cultural realities using selected interpretations of the past. Its purpose is to turn the present into a desirable future. At that, it is important to bear in mind the different types of heritage as well as the different levels of society, practical heritage management, and theoretical approaches. The heritage stories have to be like a symphony that engages all the actors in all the worlds, according to Maiste's words: "The journey towards new heritage protection is a quest for new and more extensive freedom. This means, in addition to interpreting artefacts, a deeper understanding of time and space as part of an all-encompassing system in which the spiritual encounters the physical and where miracles designate the monuments once selected by Greeks (the seven world wonders) and associated legends, rituals, the entire semiotically significant and phenomenologically rich space that allows the first one to communicate with the "other," the internal one with everything external, to become part of the universe in the same divine way as the universe becomes part of me $[. ..] . " 53$

Instead, the focus shifts from the authenticity of heritage and the correctness of historical interpretation to the way people perceive the authenticity of objects and phenomena in general, and how different historical/heritage narratives affect different social groups. ${ }^{54}$ Maiste expresses it as follows: "Heritage conservation is not a monastery, but rather a Pandora's box, one that is still waiting for someone to open - someone who would give meaning to things and answer the question of why we should keep icons holding forth of memory and locations of memory in a world where there are less and fewer things that could be considered permanent." 55

Tremendous and ultra-rapid political, environmental, and economic changes require the rapid adaptation of society and culture. Heritage must become a tool for social adaptation. The former unified national

53 Maiste, "Vabadus mäletada", 791

54 Labrador, Silberman, "Introduction: public heritage as social practice", 5 .

55 Maiste, "Vabadus mäletada”, 779. 
heritage has inevitably been fragmented, the links of people and cultures with particular places are increasingly loosening, and no one can reverse these changes. Now, the old classic heritage conservation and collection of folklore seems like a bright and nostalgic event. But those times will never come back. And those who seek it will break the last hope we have - to build up at least a tolerable natural, social, and cultural environment for the future. Heritage management to date has focused primarily on the past, leaving the future behind the blurry horizon. This means, above all that the potential of inheritance management remains largely untapped. Maiste also emphasizes the future-oriented role of heritage conservation: "Heritage conservation, as we know it today, has set itself a task that is impossible to accomplish. It is the concise portrait of our longings, which, in an ever-changing world, has set a lasting and unchanging idea on the pedestal. It has taken on a difficult (if not impossible) role to speak on behalf of the values that only cover half of the whole - to speak on the name of the past, apart from the future, which is an inevitable component of the memoria."

Heritage consists of objective phenomena (objects, historical landscapes, people, events, practices, and activities) as well as their subjective perception, related values, ideas, and meanings. Maiste also emphasizes that reducing heritage management to the preservation of tangible objects is not right: "The reduction of heritage conservation to the material dimension, as described in the Venice Charter (1964) and as it is still prevalent in our approach to heritage conservation, is at best a half-truth." Heritage is an important component of the cultural reality that people are constantly creating and that forms an important part of our living environment. On the other hand, our cultural reality today is the basis for the future, the question of "who we are" is gradually shifting to the questions "who will we become", "what will become of us tomorrow". In addition to heritage being used to explain and interpret the current situation, heritage also has a clear future-oriented purpose. ${ }^{56}$

\section{CONCLUSION}

In this article, I dealt with three major heritage management paradigms and gave examples from them in the Estonian heritage field. This was not a systematic review of the history of Estonian heritage management, but case studies aimed at highlighting the cultural ideas and concepts underlying heritage management. Each heritage management paradigm contains both theoretical and philosophical foundations as well as practices based on them.

Heritage management cannot be an activity separate from society. It is inevitably linked to all cultural, economic, and political processes taking place in society. However, the practical management of cultural heritage is influenced by different interpretations of and approaches to value. The analysis carried out clearly show that for object-based heritage management, there is a clear theoretical basis as well as institutions implementing the practice. Value-based heritage management is based on existing theory, but its practical application is still in its infancy. Theoretical basis and practices for peoplecentered heritage management still need to be established. Creation of heritage at municipal and state level has for a long time been objectbased, whereas elsewhere in the world, a shift towards value-based heritage creation began since the 1980s, and in Estonia, this process is underway. However, the transition to people-centered heritage management requires a significant revolution in the entire heritage landscape. The natural sacred places that bind the intangible and material heritage and the natural environment and their management processes obviously pave the way for more people-centered heritage management. The decisive issue for heritage management is the introduction of sustainable and more inclusive management methods. People need to be involved in heritage management on all its stages, starting from the definition of heritage and ending with its interpretation. 
Kurmo KONSA: DeVElOPMENTS IN APPROACHES TO Heritage in Estonia: MONuments, VAlues, AND PeOple Keywords: Cultural Heritage; Heritage Management; History of Heritage Management; Object-Based Heritage Management; Values-based Heritage Management; Peoples-based Heritage Management

\section{SUMMARY}

The purpose of this article is to look at the ways in which heritage is approached, based on the conceptual framework of critical inheritance research. In case of approaches to inheritance, I distinguish between object-based, value-based, and people-centered approaches depending on which aspects of the heritage are at the heart of the inheritance management process. I use different case studies from the Estonian context as examples. I am particularly interested in the changes in heritage management in the time frame of the 1970s and 1980 s to the present day.

In order to describe object-based heritage management, I will use Kalvi Aluve's book "The story about architectural monuments" (1983). It is a popular work targeted for the general public, which is why many of the views and concepts that are obviously used on a daily basis by those involved in the matter and have often become an invisible part of the work culture, are explained in detail and defined. Value-based inheritance management sets at the heart of heritage the values attributed to heritage by the various stakeholders in society. While in object-based heritage management people act as groups against the backdrop of monuments, this approach shifts the values that people attach to heritage objects and heritage phenomena to the forefront.

A value-based approach to heritage was introduced quite unexpectedly in Estonia in the late 1980s, in connection with the independence movement. Characteristically to value-based heritage management, the values related to independence and sovereignty attributed to objects became more important to people than the concrete objects themselves. As political forces and political struggles developed, purely political movements and associations became important. The paradigm of value-based heritage management then shifted to the area of natural sacred places. The value-based approach to heritage management puts communities and the values attributed by them to the heritage at the forefront, be they freedom and independence of the Estonian people, as we saw in the analysis of the heritage movement in the 1980s and 1990s, or the holiness that the Earth faith believers attribute to natural sacred places. The valuebased approach, however, greatly expands the concept of heritage, including spiritual aspects of the intangible heritage and material objects and the environment.

The decision to preserve something for future generations is, above all, a philosophical and ethical issue. People-centered inheritance management starts with addressing these issues. Estonian art historian and heritage protection philosopher Juhan Maiste is the only one who has dealt with these problems in connection with the Estonian heritage conservation in several articles and books. Below I will analyze his approach and try to highlight the connections with people-centered heritage management.

Heritage management cannot be an activity separate from society. It is inevitably linked to all cultural, economic, and political processes taking place in society. However, the practical management of cultural heritage is influenced by different interpretations of and approaches to value. The analysis carried out clearly show that for object-based heritage management, there is a clear theoretical basis as well as institutions implementing the practice. Value-based heritage management is based on existing theory, but its practical application is still in its infancy. Theoretical basis and practices for peoplecentered heritage management still need to be established. Creation of heritage at municipal and state level has for a long time been objectbased, whereas elsewhere in the world, a shift towards value-based heritage creation began since the 1980s, and in Estonia, this process is underway. However, the transition to people-centered heritage management requires a significant revolution in the entire heritage landscape. The natural sacred places that bind the intangible and material heritage and the natural environment and their management processes obviously pave the way for more people-centered heritage management. The decisive issue for heritage management is the introduction of sustainable and more inclusive management methods. People need to be involved in heritage management on all its stages, starting from the definition of heritage and ending with its interpretation. 


\section{CV}

Kurmo Konsa (b. 1965) is an Associate Professor at the Department of Archival Studies at the University of Tartu, and Professor of Conservation at Pallas University of Applied Sciences. He has an MSc in microbiology from the University of Tartu, and an MA in Book Science from Tallinn University. Kurmo Konsa holds a PhD in Informational Science from Tallinn University. His PhD thesis focuses on the preservation of written heritage and conservation surveys issues. In the past he has worked at the University of Tartu Library as a paper conservator and at the Estonian Postal Museum as Conservator and Curator of Collections. 